NBER WORKING PAPER SERIES

\title{
HETEROGENEOUS PRODUCTIVITY \\ RESPONSE TO TARIFF REDUCTION: \\ EVIDENCE FROM BRAZILIAN MANUFACTURING FIRMS
}

\author{
Adriana Schor \\ Working Paper 10544 \\ http://www.nber.org/papers/w10544
NATIONAL BUREAU OF ECONOMIC RESEARCH
1050 Massachusetts Avenue
Cambridge, MA 02138 \\ June 2004
}

I am indebted to my advisor Naércio Menezes-Filho for his suggestions and to Marc Muendler for sharing some of his data. I would like to thank Anna Maria Mayda for her helpful comments and Wasmália Bivar for making the access to IBGE data much easier. Useful comments and suggestions have been provided by the participants of the 2003 IASE-NBER Conference especially Paul Gertler. Financial support from Capes and FIPE/USP is gratefully acknowledged. The views expressed herein are those of the author(s) and not necessarily those of the National Bureau of Economic Research.

(C2004 by Adriana Schor. All rights reserved. Short sections of text, not to exceed two paragraphs, may be quoted without explicit permission provided that full credit, including $(\mathbb{C}$ notice, is given to the source. 
Heterogeneous Productivity Response to Tariff Reduction: Evidence from Brazilian Manufacturing Firms

Adriana Schor

NBER Working Paper No. 10544

June 2004

JEL No. F1, L1, L6, O3

\section{$\underline{\text { ABSTRACT }}$}

This paper studies the effects of trade liberalization on the evolution of firm productivity. The productivity of each firm was estimated using an unbalanced panel data of 4,484 Brazilian manufacturing firms from 1986 to 1998, following the procedure first proposed by Olley and Pakes (1996) and further developed by Levinsohn and Petrin (2003). First, the effect of nominal tariffs on firms' productivity levels is identified. After controlling for the endogeneity of nominal tariffs, the estimated coefficient for tariffs in the productivity equation turns out to be negative. Second, a measure of tariffs on inputs is added in the productivity equation. The coefficient associated with tariffs on inputs is also negative, and the inclusion of this new variable reduces the size of the estimated coefficient of nominal tariffs. Thus, it seems that, along with the increased competition, the new access to inputs that embody better foreign technology also contributes to productivity gains after trade liberalization. Third, it is shown that there is a huge degree of heterogeneity of responses to trade liberalization. The effect of the tariff reductions depends heavily on observed and unobserved characteristics of the firm.

Adriana Schor

Department of Economics

Fundação Getúlio Vargas

Av. Nove de Julho 2029 - 11 andar

São Paulo, SP 01313-902 Brazil

aschor@fgvsp.br 


\section{Introduction}

There is plenty of evidence that tariff reduction increases the efficiency of manufacturing firms. Tybout, de Melo and Corbo (1991) studied the impact of trade liberalization on the performance of Chilean firms in the 70's. They concluded that industries that experienced higher tariff reductions were the same as those that experienced higher efficiency gains. Similar results were found by Harrison (1994) for the Ivory Coast, by Iscan (1998) for Mexico and by Hay (2001) for Brazil. More recently, several papers sharing similar methodology, which solves some econometric problems regarding productivity estimation, also tried to answer whether trade liberalization enhances firm productivity gains. Pavcnik (2002) found that the in-plant productivity improvements in Chile can be attributed to trade liberalization. Fernandes (2003) and Muendler (2002) using data from Colombia and Brazil, respectively, found a negative relationship between nominal tariffs and productivity, reinforcing the perception that trade liberalization has a positive impact on productivity. Tybout (2000 and 2001) surveys several papers on productivity and trade, based on firm-level databases.

However, little has been said about the channels through which tariff reduction affects productivity. Usually, trade liberalization is seen as a sharp reduction in nominal tariffs that leads to a much higher degree of competition in domestic markets, which in turn pushes firms to reduce inefficiencies. The other - less examined - side of trade liberalization and nominal tariff reduction is the reduction of tariffs on inputs, which

reduces the costs and increases the access to foreign intermediate and capital goods by domestic firms. The overall reduction of nominal tariffs leads not only to a reduction of tariffs on inputs but also creates an incentive for firms to adopt outsourcing strategies. From a theoretical point of view, both embodied technology in imported inputs and outsourcing can explain productivity gains when trade increases.

Muendler (2002) seems to be the first attempt to deal with this issue. Besides testing the effect of nominal tariffs on productivity, he explicitly includes foreign capital and intermediate inputs in the production function, to test whether firms with higher usage of foreign inputs have higher productivity.

Here a very similar hypothesis is tested: whether increased availability of foreign inputs (intermediate and capital goods) affects the firm's productivity. The approach, 
however, is different. Here, instead of considering the impact of trade liberalization on the observed volume of imported inputs, the impact of tariff reduction on the intermediate and capital good markets is considered. The first reason to do so is because imported inputs may be used by firms indirectly, since most of manufacturing inputs undergo local remanufacturing. Secondly, it tests the impact of trade policy more directly.

Another point discussed in this paper is the heterogeneous response to tariff reduction. It is a stylized fact that there is a substantial difference between and withinindustry heterogeneity in output, input and productivity in the manufacturing sector. Thus, it is relevant to ask whether the average impact of tariff reduction is representative for most of the firms, or if there is substantial cross-firm variation in the productivity response to reduced tariffs. To sort out the effect of trade liberalization on different firms, these firms were classified according to observed and unobserved characteristics, and the estimation of the impact of decreased tariffs is conditioned on such characteristics.

To address these questions, I use a data set of Brazilian manufacturing firms, which has information on production and inputs used by those firms between 1986 and 1998 . Brazil, as many Latin-American countries, relied heavily on import-substitution industrialization programs for decades. Although a very diversified industrial sector flourished in the country, the firms faced a very protected environment with very limited competition from abroad and reduced access to imported inputs and capital goods.

In less than a decade, Brazilian trade policy suffered a significant change. Average nominal tariffs decreased from $77 \%$ in 1987 to $13.6 \%$ in 1994 . The tariff dispersion was also sharply reduced. The standard deviation fell to $8.4 \%$ in 1994 from $53.8 \%$ in 1987 . Despite the fact that there was a relative setback in the last half of the 90's, the decade ended with nominal tariffs 20 percentage points below their initial value. Brazilian manufacturing firms were undoubtedly much less protected than before. The impact on the volume of imports was also very significant. During the 90's, imports grew 170\%, almost $10.5 \%$ per year. Imports of capital goods increased 196\% and of intermediate goods, $259 \%$. Import penetration, according to Moreira (2000) rose from 4.5\% in 1989 to $19.3 \%$ in 1998.

This paper yields important findings. First, it shows that both nominal tariffs and tariffs on inputs have a negative impact on firm productivity. Thus, it seems that along with higher competition, new access to better inputs also contributes to enhance productivity 
after trade liberalization. Second, it argues that the effect of trade liberalization upon a representative firm is not the best way to evaluate the impact of tariff reduction on the productivity of a given firm. There is much heterogeneity in the response to trade liberalization, and this heterogeneity is far from random. Observed and unobserved characteristics of firms can explain why firms react differently when tariffs are reduced.

The remainder of this paper is organized as follows. The next two sections describe the Brazilian trade liberalization process and the data. Section 4 presents the structural model and how it is implemented to yield a measure of firm productivity. Section 5 relates to productivity and tariffs, while section 6 shows the heterogeneity of such relationships among different firms. The last section presents a summary and conclusions.

\section{Brazilian Trade Liberalization ${ }^{1}$}

Until the end of the 80 's, Brazilian trade policy meant extremely high nominal tariffs and a huge amount of non-tariff barriers. Nominal tariffs were in general redundant. The price difference between domestic and international prices was much lower than the tariffs suggested. Imports were restricted not because of high nominal tariffs, but mainly by innumerous non-tariff restrictions like lists of prohibited imported goods, difficult access to government import authorization and limits on imports for each firm. On the other hand, there were several exception rules that reduced both the tariff and the non-tariff barriers for the import of some specific goods.

In 1988 there was the first attempt to rationalize trade policy. Some of the non-tariff barriers were extinguished (elimination of some taxes on imported goods and some of the special regimes faced by several industries) and nominal tariffs had a small reduction.

In 1990, the newly elected government announced a new trade policy that would change substantially the old regime. At first, all but a few non-tariff barriers were eliminated. Trade policy thereafter would rely mostly on tariffs and on exchange rate management (although the exchange rate regime was much more flexible than before). Secondly, a four-year schedule of tariff reductions was announced. After these four years, the tariff range would be between $0 \%$ and $40 \%$. The average tariff would decrease from slightly lower than 50\% in 1989 to $14 \%$ in 1994. According to Kume, Piani and Souza

\footnotetext{
${ }^{1}$ This section relies heavily on Kume, Piani and Souza (2000).
} 
(2000), at first there was no discrimination among industries except for a higher protection for the production of goods with high technological requirements such as computers, some chemical sectors and biotechnology. The tariff structure was designed according to the comparative advantage, the initial tariff level and tariff on inputs. There were some exceptions, but the result was a much more rational tariff structure.

The schedule of tariff reduction was constructed so as to have first a reduction of tariffs on inputs and only then a more aggressive reduction of tariffs on consumer goods. The program was fully implemented in the second semester of 1993 - several months before schedule.

After the stabilization plan was launched in July of 1994, there was a further push to reduce tariffs, mainly on those goods that had a significant impact on inflation indices. In order to increase the supply of imported goods to discipline domestic prices, there was also an anticipation of the adoption of the Mercosur common external tariff, which in several cases implied a reduction in current tariffs. If the Mercosur tariff was higher than the current one, the lower tariff was maintained. Trade policy during this period had an important role in helping to stabilize inflation in Brazil.

However, the Mexican crisis in December of 1994, the currency overvaluation due to the huge capital inflows observed after the introduction of the Real and the huge increase in imports led to a revision of the recent trade policy changes, since the external imbalance became a major concern. Tariffs were increased as the government asked for the inclusion of several goods in the exception list, since by this time Mercosur imposed some restrictions on tariff rises. As a result, from 1995 to 1998 the nominal average tariff went up almost 3 percentage points, from $12.8 \%$ to $15.5 \%$.

\section{Data: Pesquisa Industrial Anual}

The data source used to construct measures of productivity is the Pesquisa Industrial Anual (PIA) carried out by Instituto Brasileiro de Geografia e Estatistica (IBGE), the Brazilian census bureau. PIA collects firm-level economic data annually since 1986 excluding 1991.

Firms are qualified to enter in the PIA sample if they have at least half of their income related to industrial activity. The initial sample was based on the 1985 industrial 
census and includes all of the biggest industrial firms and a random sample of mediumsized firms. All newly founded firms were supposed to be included yearly, although it seems that the surveying method was not rigorously applied ${ }^{2}$. After cleaning the dataset ${ }^{3}$, the sample of firms utilized in this study is of 4,844 firms, compared to a total of 9,130 firms identified with at least one year of positive sales. Table 1 displays the number of firms in each industry for different periods of time. The reduction of the number of firms in the sample is due to several factors. The most direct one is the fact that new entries were not fully incorporated in the survey sample before 1996. The change in the questionnaire after 1996 in which the balance sheet data are no longer reported implied that only firms sampled in 1995 were kept in the sample for the following years, since the construction of a capital series was then changed to the perpetual inventory method. There are certainly other factors that may have contributed to the reduction of the number of firms, probably related to trade liberalization, such as mergers and acquisitions and the exit of firms that did not adapt to the new liberalized economic environment.

PIA contains information on the number of production and non-production workers, sales, inventories of inputs and of produced goods and other inputs (materials). There is also balance sheet data, which allows us to construct a capital stock series. In table 1 some information is displayed regarding these variables.

Unfortunately, information on sales, inventories and materials are given at nominal levels at the end of each calendar year. Due to extremely high inflation during most of the period covered by the survey, each series was first inflated so that it best represented the sum of the monthly values at the end of the year, and only then converted to a common currency - reais as of August of 1994. Although this procedure is necessary, one should bear in mind that these variables may suffer from measurement errors. The higher the inflation and price dispersion, the higher the error.

The capital stock was the only item in the balance sheet that was indexed to the official inflation rate until 1995. However, the official correction was systematically below the observed inflation rate, calculated by several organizations (even by the government).

\footnotetext{
${ }^{2}$ Muendler (2001) offers a complete and detailed description of PIA's sample procedure and the survey's contents.

${ }^{3}$ The outliers were discarded (1\% of the highest and lowest values for labor-production, capital-production and materials-production ratios) as well as firms with less than two consecutive observations. The dataset was carefully screened and clearly misreported values were also discarded.
} 
The series was then corrected for this and real August 1994 values used. One possible setback of this series is the fact that the government, recognizing that official correction systematically reduced the real value of capital stock, allowed firms to make a once-andfor-all optional correction in their capital stock in 1991, by the amount they judged it was undervalued. Since the survey was not carried out this year, it is impossible to say which firms made the correction and by what amount. I thus utilized here the uncorrected series. After 1995, PIA stopped collecting information on capital stock. Since only investment values were available, only firms that were in the sample before this year were included, and the capital stock was calculated adding the investment net of depreciation to the previous year's capital stock.

In order to estimate the production functions that will allow me to measure firms' productivity, firms were grouped in 27 manufacturing industries (close to two-digit SIC classification - or nível 50 in the Brazilian industrial classification). As table 1 shows, there is a significant difference in firms' characteristics across industries and, especially, within industries, represented by the standard deviation higher than the average.

Data on nominal tariffs is available from 1986 to 1998 for industries classified according to nível 100 in the Brazilian industrial classification (close to three-digit SIC classification) from Kume, Piani and Souza (2000). Tariffs on inputs were constructed using input-output tables, available for 1985 and annually from 1990 to 1996. For each industry a vector of inputs is associated with nominal tariffs to give tariffs on inputs.

Average nominal tariffs and average tariffs on inputs are displayed for the 27 manufacturing industries in table 1 . There is significant variation of tariffs over time and across industries.

\section{Productivity Measure}

Productivity is usually calculated as the difference between the observed output and the output predicted by an estimated production function. Thus, the main empirical concern is how to estimate an unbiased production function. Let us suppose that the technology of firm $i$ is well described by a Cobb-Douglas production function:

$\mathrm{y}_{\mathrm{it}}=\beta_{0}+\beta_{\mathrm{lw}} \mathrm{lw}_{\mathrm{it}}+\beta_{\mathrm{lb}} \mathrm{lb}_{\mathrm{it}}+\beta_{\mathrm{m}} \mathrm{m}_{\mathrm{it}}+\beta_{\mathrm{k}} \mathrm{k}_{\mathrm{it}}+\mu_{\mathrm{it}}$ 
where $y_{i t}$ is the gross output, $\mathrm{lw}_{\mathrm{it}}$ and $\mathrm{lb}_{\mathrm{it}}$ are the amount of labor on administrative tasks and on production, respectively, $\mathrm{m}_{\mathrm{it}}$ is the quantity of other inputs (materials) and $\mathrm{k}_{\mathrm{it}}$ is the stock of capital used by firm $i$ in time $t$. The firm $i$ specific residual term $\mu_{\mathrm{it}}$ can be decomposed as $\mu_{\mathrm{it}}=\omega_{\mathrm{it}}+\varepsilon_{\mathrm{it}}$, where $\omega_{\mathrm{it}}$ is an efficiency term (or productivity level) that is known by the firm but not by the econometrician and $\varepsilon_{\text {it }}$ is an unexpected productivity shock (unobserved both by the firm and the econometrician and with zero mean).

The fact that $\omega_{\text {it }}$ is known by the firm when it takes the decision as to whether to stay in the market and produce and, if deciding to produce, which input combination to use, makes the OLS estimate of the production function biased. The error term is not uncorrelated with the explanatory variables, the key assumption for OLS to produce unbiased estimates. There is not only a simultaneity bias, that arises due to the fact that the unobserved efficiency level is taken into account when the firm decides what input combination and quantities it will use to produce, but also a selection bias, which comes from the fact that the firm chooses whether to stay in the market or exit after it knows its productivity level $\omega_{\mathrm{it}}$, which is not observed by the econometrician.

The alternative is to use fixed-effects to correct for this bias, assuming that $\omega_{i t}$ is firm-specific but constant over time. However, during periods of substantial changes in the economic environment, it is not a reasonable assumption to let a firm's productivity be fixed over time. In fact, I am interested in measuring the change occurred in productivity due to trade liberalization.

So far, the standard alternative to solve the bias introduced by acknowledging that $\omega_{\text {it }}$ is known by the firm but not by the econometrician is given by Olley and Pakes (1996). Starting from the same production function described above, they propose an econometric method based on a structural model that is able to solve both the simultaneity and the selection bias.

Those authors developed a model where the firm maximizes its expected current and future profit values. In each period the firm decides whether to exit the market or to continue to produce, by comparing the net profit cash flow and the exit value. If it decides to produce, it chooses the inputs. The firm-specific efficiency factor is known at the beginning of time $t$ and determines the firm's choices. 
To overcome the fact that $\omega_{\text {it }}$ is not observed by the econometrician, they write down an investment function that depends on the unobserved efficiency variable and the capital stock. Assuming that investment is always positive if the firm decides to continue in the market, it is possible to invert this function and write $\omega_{i t}$ as a function of the observed capital stock and investment made by the firm in time $t$.

I follow quite closely the Olley and Pakes (1996) methodology (O-P hereafter). However, a few changes need to be made to make sure that the proposed method is suitable for the Brazilian data set I work with.

First, I cannot use investment as a proxy for the unobserved efficiency variable because in my data set most of the firms, most of the years, do not have positive investment. Pavcnik (2002) shows that there is a significant change in the estimated coefficients when you include the zero-investment observations. Levinsohn and Petrin (2003) recognize that observing lots of zero-investment observations is a common feature of developing country data sets. They propose to use other inputs as a proxy for the unobserved efficiency variable.

Second, it is not a reasonable assumption to set labor as a free mobile factor as it is assumed in O-P algorithm. In Brazil, due to the high cost of dismissing workers, firms at first adjust the labor requirement by adjusting the working hours. Only when significant changes in production or in technology take place is there a change in the number of workers. Since the information on firms' labor usage is on the number of workers, labor seems to be better treated as a state variable.

Third, O-P addresses the selection bias by explicitly modeling the firm's probability of continuing in the market as a function of the observed variables. Although PIA provides the information as to whether a firm is active or exited, there are several observations in which a firm is not producing but did not choose to exit definitively (it is said to be paralyzed). Moreover, some firms cease appearing in my sample without any information as to whether they exited or if it is a missing observation. As a consequence, I do not explicitly correct for the selection bias. Levinsohn and Petrin (2003), however, argue that by using an unbalanced panel of firms, the selection bias is significantly minimized. 


\subsection{Structural Model and Implementation}

As before, firm $i$ 's technology can be described as a Cobb-Douglas production function such as

$$
\begin{aligned}
& \mathrm{y}_{\mathrm{it}}=\beta_{0}+\beta_{\mathrm{lw}} \mathrm{lw}_{\mathrm{it}}+\beta_{\mathrm{lb}} \mathrm{lb}_{\mathrm{it}}+\beta_{\mathrm{m}} \mathrm{m}_{\mathrm{it}}+\beta_{\mathrm{k}} \mathrm{k}_{\mathrm{it}}+\mu_{\mathrm{it}} \\
& \mu_{\mathrm{it}}=\omega_{\mathrm{it}}+\varepsilon_{\mathrm{it}}
\end{aligned}
$$

The unobserved productivity level variable $\omega_{\text {it }}$ is assumed to follow a $1^{\text {st }}$ order Markov process. The expected value of $\omega_{i t}$ is a function of an unexpected shock with zero mean and of its value at time $t-1$.

$\omega_{\mathrm{it}}=\omega_{\mathrm{it}-1}+\zeta_{\mathrm{it}} \Rightarrow \omega_{\mathrm{it}}=\mathrm{E}\left(\omega_{\mathrm{it}} / \omega_{\mathrm{it}-1}\right)+\zeta_{\mathrm{it}}$

Besides labor and capital, the firm needs other inputs (materials) to produce according to the above production function. The demand for these other inputs is a function of the efficiency variable $\omega_{\text {it }}$ and of the state variables, labor and capital. The usage of these other inputs is adjusted immediately to different states of the efficiency variable, or productivity. Labor and capital, on the other hand, take time to adjust due to adjustment costs.

$$
\mathrm{m}_{\mathrm{it}}=\mathrm{f}_{\mathrm{t}}\left(\omega_{\mathrm{it}}, 1 \mathrm{w}_{\mathrm{it}}, \mathrm{lb}_{\mathrm{it}}, \mathrm{k}_{\mathrm{it}}\right)
$$

It seems reasonable to assume ${ }^{4}$ that the above function is monotonic in $\omega$. That is, given the stock of capital and labor in time $t$, the higher the productivity or efficiency level, the higher the usage of materials, since the firm will produce more than another firm that has the same stock of capital and labor but lower productivity. Thus, we can invert the above equation and write $\omega_{\text {it }}$ as a function of the observed variables, materials, labor and stock of capital.

\footnotetext{
${ }^{4}$ Levinsohn and Petrin (2003) detail the necessary conditions for the monotonicity of this function.
} 
$\omega_{\text {it }}=h_{t}\left(m_{i t}, l_{\text {it }}, \mathrm{lb}_{\mathrm{it}}, \mathrm{k}_{\mathrm{it}}\right)$

Substituting this equation in the production function, we have

$\mathrm{y}_{\mathrm{it}}=\varphi_{\mathrm{t}}\left(\mathrm{m}_{\mathrm{it}}, \mathrm{lw}_{\mathrm{it}}, \mathrm{lb}_{\mathrm{it}}, \mathrm{k}_{\mathrm{it}}\right)+\varepsilon_{\mathrm{it}}$

where $\varphi_{\mathrm{t}}\left(\mathrm{m}_{\mathrm{it}}, 1 \mathrm{w}_{\mathrm{it}}, \mathrm{lb}_{\mathrm{it}}, \mathrm{k}_{\mathrm{it}}\right)=\beta_{0}+\beta_{l w} l w_{i t}+\beta_{l b} l b_{i t}+\beta_{m} m_{i t}+\beta_{k} k_{i t}+h_{t}\left(\mathrm{~m}_{\mathrm{it}}, 1 \mathrm{w}_{\mathrm{it}}, \mathrm{lb}_{\mathrm{it}}, \mathrm{k}_{\mathrm{it}}\right)$.

As in Olley and Pakes (1996) and Pavcnik (2002), the function $\varphi_{\mathrm{t}}$ is approximated by a polynomial series on the observed variables - materials, labor and capital stock. Since an underlying assumption is that the input market is not only the same for all firms but also that the market structure does not change over time, the function $\varphi_{t}$ is estimated for three distinct periods (1986-1990, 1992-1994, 1995-1998) to take into account the changes observed in the Brazilian economy. Thus, the first stage of the O-P procedure is to estimate $\varphi_{\mathrm{t}}$

The assumption that the firm's efficiency follows a $1^{\text {st }}$ order Markov process allows us to write its expected value as a function of its past value

$\mathrm{E}\left(\omega_{\mathrm{it}} / \omega_{\mathrm{it}-1}\right)=\mathrm{g}\left(\omega_{\mathrm{it}-1}\right)$

The $g($.$) function can then be expressed as a function of the past values of the$ observed variables by replacing $\omega_{\mathrm{it}-1}$ with the functions $\mathrm{h}_{\mathrm{t}-1}$ and $\varphi_{\mathrm{t}-1}$.

$$
\begin{aligned}
\mathrm{g}\left(\omega_{\mathrm{it}-1}\right) & =\mathrm{g}\left(\mathrm{h}_{\mathrm{t}-1}\left(\mathrm{~m}_{\mathrm{it}-1}, \mathrm{lw}_{\mathrm{it}-1}, \mathrm{lb}_{\mathrm{it}-1}, \mathrm{k}_{\mathrm{it}-1}\right)\right) \\
& =\mathrm{g}\left(\varphi_{\mathrm{t}-1}\left(\mathrm{~m}_{\mathrm{it}-1}, \mathrm{lw}_{\mathrm{it}-1}, \mathrm{lb}_{\mathrm{it}-1}, \mathrm{k}_{\mathrm{it}-1}\right)-\beta_{0}-\beta_{\mathrm{lw}} \mathrm{lw}_{\mathrm{it}-1}-\beta_{\mathrm{lb}} \mathrm{lb}_{\mathrm{it}-1}-\beta_{\mathrm{m}} \mathrm{m}_{\mathrm{it}-1}-\beta_{\mathrm{k}} \mathrm{k}_{\mathrm{it}-1}\right)
\end{aligned}
$$


Using the predicted values of $\varphi_{\mathrm{t}-1}$ estimated in the first stage, we can then estimate in a second stage the coefficients associated with the observed variables by non-linear least squares of the function below

$$
\begin{aligned}
\mathrm{y}_{\mathrm{it}}= & \beta_{0}+\beta_{\mathrm{lw}} \mathrm{lw}_{\mathrm{it}}+\beta_{\mathrm{lb}} \mathrm{lb}_{\mathrm{it}}+\beta_{\mathrm{m}} \mathrm{m}_{\mathrm{it}}+\beta_{\mathrm{k}} \mathrm{k}_{\mathrm{it}}+ \\
& +\mathrm{g}\left(\varphi_{\mathrm{t}-1}\left(\mathrm{~m}_{\mathrm{it}-1}, \mathrm{lw}_{\mathrm{it}-1}, \mathrm{lb}_{\mathrm{it}-1}, \mathrm{k}_{\mathrm{it}-1}\right)-\beta_{0}-\beta_{\mathrm{lw}} \mathrm{lw}_{\mathrm{it}-1}-\beta_{\mathrm{lb}} \mathrm{lb}_{\mathrm{it}-1}-\beta_{\mathrm{m}} \mathrm{m}_{\mathrm{it}-1}-\beta_{\mathrm{k}} \mathrm{k}_{\mathrm{it}-1}\right)+\zeta_{\mathrm{it}}+\varepsilon_{\mathrm{it}}
\end{aligned}
$$

\subsection{Estimation}

A production function was estimated for each of the 27 industries using the equation and methodology discussed above. In table 2 the estimated coefficients for each industry and corresponding OLS estimates are displayed.

Most of the coefficients associated with the capital stock estimated by the O-P methodology are larger than the OLS estimates (23 out of 27), which evidences that the simultaneity bias is strong with OLS estimation. ${ }^{5}$

The standard errors shown are not corrected for the fact that in the second stage the non-linear least squares uses estimated variables instead of the true ones. Although in Olley and Pakes (1996) there is not much difference between the corrected and the uncorrected standard deviation when using the series approximation, it seems important to confirm their findings. Bootstrapped standard deviations were calculated for only one fifth of the industries due to the heavy computational time required. Although they are higher than the analytical ones, they do not seem to change either the significance of the estimated coefficients or the conclusion that the O-P algorithm produces higher capital coefficient estimates than the OLS ones.

To have a measure of firm productivity, I followed Pavcnik (2002) and Aw et al. (2001) and constructed a productivity index that can describe both the evolution of the productivity of the firm over time and its relative position compared to a reference firm in a reference year.

\footnotetext{
${ }^{5}$ If capital stock and labor usage are positively correlated, and both capital and labor are correlated to the productivity variable, (which seems to be the case) then the estimated coefficient on capital tends to be underestimated and the labor coefficient tends to be over-estimated. Levinsohn and Petrin (2000) discuss further the sign of the bias.
} 
In this case the reference firm is a synthetic firm, which has the mean output, labor, capital and materials usage of each industry in 1986. To put it more clearly, the productive measure $\operatorname{prod}_{i t}$ is calculated as follows

$\operatorname{prod}_{\mathrm{it}}=\mathrm{y}_{\mathrm{it}}-\hat{\beta}_{\mathrm{lb}} \mathrm{lb}_{\mathrm{it}}-\hat{\beta}_{\mathrm{lw}} \mathrm{lw}_{\mathrm{it}}-\hat{\beta}_{\mathrm{m}} \mathrm{m}_{\mathrm{it}}-\hat{\beta}_{\mathrm{k}} \mathrm{k}_{\mathrm{it}}-\left(\mathrm{y}_{\mathrm{r}}-\hat{\mathrm{y}}_{\mathrm{r}}\right)$

where $\mathrm{y}_{\mathrm{r}}=\overline{\mathrm{y}}_{\mathrm{it}}$ and $\hat{\mathrm{y}}_{\mathrm{r}}=\hat{\beta}_{\mathrm{lb}} \overline{\mathrm{l}}_{\mathrm{it}}+\hat{\beta}_{\mathrm{lw}} \overline{\mathrm{l}}_{\mathrm{it}}+\hat{\beta}_{\mathrm{m}} \overline{\mathrm{m}}_{\mathrm{it}}+\hat{\beta}_{\mathrm{k}} \overline{\mathrm{k}}_{\mathrm{it}}$. The bar over each variable denotes the simple average of all firms of each industry in 1986.

Table 3 shows that there is a lot of heterogeneity of productivity evolution between different manufacturing industries in this period. It is also important to point out that the evolution of productivity within an industry over time is far from regular. From one year to another, productivity measures change a lot in most of the industries. That is not surprising, given the huge macroeconomic instability and several different policies that were implemented in Brazil over the 13 years that the data set covers.

\section{Productivity and Tariffs}

The first empirical concern, when addressing the question of whether the reduction of tariff barriers observed over the last years of the 80's and the first years of the 90's affected firms' productivity, is how to disentangle the effects of trade liberalization from other changes in macroeconomic policy. One way to do that is to include year (or period, or before-and-after) dummies as explanatory variables in the regressions. This treatment is sufficient to guarantee consistent estimators if we believe that the sector-specific impact of other macroeconomic policies is not correlated with the sector-specific tariff reduction observed in the period. Certainly, there is a connection between reduction of tariffs and other policies adopted over this period (privatization, disinflation, financial liberalization), but it is reasonable to assume that the reduction of trade protection across industries is relatively independent from other kinds of macro policy. Given this assumption, I used year dummies to control for any other policy that affected all industries over this period (although each industry responded differently to these policies, I assume that they are not correlated with the tariff structure). 
Another concern relates to the political economy of tariff reduction. From the policy maker's point of view, the choice regarding which industry should be more protected and which industry needs more competition is far from random. On the other hand, it is reasonable to assume that firms pressure policy makers for more protection, either through higher tariffs on its competing imported goods, or through a reduction in tariffs on the inputs they use. Ferreira (2000) argues that there is a positive correlation between nominal tariffs and industry concentration in Brazil. Using a panel data set of Brazilian industries from 1988 to 1994, he shows that the more concentrated the industry, the higher its nominal tariff in relation to other industries. As a result, it is difficult to assume that tariffs are exogenous in a regression where productivity is on the left hand side. In both cases, from the policy makers' or from the lobby's point of view, we can argue that the tariff is correlated with productivity. In the first case, policy makers may have used trade policy to induce more competition in industries in which they might have thought that the lack of foreign goods in the domestic market had had a negative impact on productivity. Lobbies in low productivity sectors, on the other hand, may have pressured for higher tariffs to maintain the domestic market closed to foreign competition.

It is not easy to find good instruments for nominal tariffs. A good instrument should be correlated not only with the time trend but also with the cross-industry pattern of the tariff structure and uncorrelated with the productivity measure. However, in the Brazilian case, the trade liberalization process changed the structure of protection very little. The Spearman rank correlation of nominal tariffs among the 27 industries between 1986 and 1998 is above $80 \%$. From 1989 on, the year-by-year correlation is above 87\%. It seems that the political economy behind the tariff reduction did not change much during the period analyzed. As a consequence, using industry dummies that control for these time-invariant characteristics of the political economy of trade liberalization can reduce significantly the bias in the OLS regression. This is the same assumption used in Goldberg and Pavcnik (forthcoming).

When estimating the relationship between protection and productivity, I left aside the period between 1986 and 1988. As Kume, Piani and Souza (2001) argue, the tariff reduction observed in these years was mainly due to the reduction of redundant tariffs. There was not much change in the environment of protection that most domestic firms were 
facing. Thus, including this data will bias the estimated relation between productivity and protection, since productivity changes over this period are not related to changes in protection.

Table 4 shows the results of OLS regressions of productivity on nominal tariffs. Once industry dummies are included, the sign of the coefficient related to nominal tariffs changes from positive to negative, although it is not significant. When firms' fixed-effects were included to correct a bias that may arise because the production function is estimated for each industry and not for each firm, the coefficient not only is negative but is also significant at $1 \%$. This result confirms that using dummies (for industries and firms) reduces the bias found in the OLS regression. This result is maintained when the OLS productivity measure is used.

The fact that nominal tariffs are negatively correlated with productivity was often associated with competition being the main source of increased productivity observed in some industries. Even the reduction of productivity in some other industries could be explained by the inability of domestic firms to compete with more productive foreign firms. Those firms reduced production, which in the short run (given that labor and capital take time to adjust) means lower productivity.

However, the reduction in tariffs leads to a reduction also in the price of imported inputs necessary for production. It also certainly increases the supply of these inputs, which are often thought of as having a better quality-price ratio, and which can increase productivity through the embodied technology transferred from more advanced economies. To proxy this greater availability of foreign inputs I used a measure of tariffs on inputs. The measure of the tariffs on inputs was constructed using the nominal tariff of each industry and input-output tables.

Adding this measure of tariffs on inputs to the above regression (table 5), the sign of the coefficient of nominal tariffs (using industry dummies and firms' fixed-effects) did not change. The magnitude, however, is much lower. Part of the effect is now captured by the coefficient related to tariffs on inputs.

In general, the sizes of the coefficients associated with each of the tariff measures are similar. This result can be interpreted as evidence that the availability of imported inputs also plays a role in enhancing firms' productivity. We can also say that it is likely 
that the impact of increased competition on productivity is not much larger than the impact of the possibility of using imported inputs in production.

\section{Heterogeneous Response to Tariff Reduction}

One stylized fact of the manufacturing sector is that there is huge heterogeneity between firms in different industries and also among firms in the same industry. The Brazilian case is no exception. Therefore, the above results, although true for an average firm, are not sufficient to disentangle the effects of tariff reduction on firms' productivity.

Thus, I make here an attempt to have a more precise answer concerning the relationship between productivity and tariffs, by conditioning the above results on the firms' characteristics. First, the firms were classified according to some observed characteristics such as size, type of good produced (capital, intermediate, transport and consumer goods), type of technology used (capital, labor, natural resources and technology intensive), industry concentration (Herfindahl), initial nominal tariffs and imports and exports as a percentage of production, as table 6 shows.

Firms were considered small when they have less than 50 workers the first year they are sampled and large if they have more than 500 workers at that time. Firms were classified as having low or high import and export share, Herfindahl index and initial tariffs, if they belong to industries in the first and last quarter of the distribution of these variables in 1986.

When conditioning for the firms' characteristics, the general result that productivity is higher with lower nominal tariff and lower tariff on inputs is no longer true. Not only are some of the estimated coefficients not statistically significant, but also some of them have the opposite sign (higher tariffs implies higher productivity). Table 7 presents the marginal effects of an increase of nominal tariff and on tariffs on inputs for different firm characteristics. Although this is a very interesting point, the results are in general not very robust to different specifications.

Table 8 shows that productivity dispersion is extremely high among firms of the same industry, which raises the hypothesis that there are still significant differences among these firms that are not explained by characteristics related to specific industries. These unobserved characteristics can possibly affect the relationship between productivity and 
tariffs. To capture those unobserved characteristics quantile regressions ${ }^{6}$ were estimated. The assumption is that the relative position of the firm in the industry productivity distribution is related to some of these unobserved characteristics such as management quality.

The quantile regression results for the nine deciles of the productivity distribution are shown at table 9. There is a clear-cut distinction between the effect of nominal tariffs and of tariffs on inputs on the productivity of the firms when they are classified according to their relative productivity. The productivity of the less productive firms (the first decile) increases when both nominal tariffs and tariffs on inputs are reduced. For more productive firms, the marginal effect of a reduction in nominal tariffs is positive.

The general result is that while a reduction in tariffs on inputs has a similar and positive effect on firm productivity, the marginal effect of the reduction of nominal tariffs varies significantly across firms. It is positive for firms at the lower end of the distribution but turns out to be negative for the most productive firms. Unlike the analysis concerning observed characteristics, the above results are robust to different specifications.

The first impact of a tariff reduction is to reduce productivity of domestic firms due to the lower production resulted from a reduced market share. Since some inputs are fixed in the short run, lower production means lower productivity. However, firms at the lower end of productivity distribution cannot stay in the newly liberalized market unless they increase productivity. Muendler (2002) shows that when tariffs are reduced, higher competition from foreign firms leads to a higher probability of firms with low productivity exiting the market. Thus, firms at the lower end of productivity distribution have to work hard and fast to increase productivity. The same does not happen to firms with higher productivity.

In the quantile regression, only firms at the low end of productivity distribution that were able to increase productivity are sampled. Firms that were not successful in increasing productivity left the market. This can be an explanation for the results from quantile regressions: firms that face higher probability of exiting the market are the ones that respond faster to higher foreign competition from tariff reduction.

\footnotetext{
${ }^{6}$ A complete reference for quantile regression is Buchinsky (1998).
} 
Where tariffs on inputs are concerned, both firms with high and low productivity adapt at the same pace, increasing the share of foreign inputs, which in turn leads to higher productivity.

\section{Summary and Conclusions}

This paper studies the effects of trade liberalization in Brazil on the evolution of firm productivity. The productivity of each firm was estimated using an econometric framework that avoids the endogeneity bias incurred by the ordinary OLS production function estimation. Using an unbalanced panel data of 4,484 Brazilian manufacturing firms from 1986 to 1998 , I estimated 27 industry production functions, following the procedure first proposed by Olley and Pakes (1996) and further developed by Levinsohn and Petrin (2003).

The fact that nominal tariff changes are not independent from firms' productivity is usually a problem in OLS regressions, where productivity is on the left hand side of the equation. The bias introduced by the political economy of trade protection cannot be known

a priori, since policy makers and firms may have different incentives to lobby for tariff movements. The choice of good instruments for nominal tariffs is always problematic. In the Brazilian case, however, the fact that the structure of protection did not seem to have changed much after trade liberalization means that, by using industry dummies, the OLS bias can be significantly reduced. The positive correlation between productivity levels and nominal tariffs turns out to be negative when such fixed effects are added to the estimated equation.

Due to the estimated negative marginal effect of nominal tariffs on productivity, it is usually agreed that trade liberalization promotes productivity gains by inducing domestic firms to reduce $\mathrm{X}$-inefficiencies and trim their fat in order to compete with more productive foreign firms. However, using tariffs on inputs to proxy for the increased availability of foreign inputs with better foreign technology, I found that tariffs on inputs also have a negative marginal effect on productivity. Thus, it seems that, along with the higher competition, new access to better inputs also contributes to productivity gains after trade liberalization. 
The above statement, however, is not valid for every firm. There is a huge degree of heterogeneity of responses to trade liberalization. The effect of tariff reductions depends on the characteristics of the firm, such as size, type of good it produces, type of technology it uses, degree of concentration of the industry it belongs to, initial nominal tariffs and the share of imports and exports. It also depends on unobserved characteristics here proxied by the relative position in the productivity distribution of the industry the firm belongs to.

\section{References}

Aw, B.Y., X. Chen e M.J. Roberts (2001) "Firm-level Evidence on Productivity Differentials and Turnover in Taiwanese Manufacturing”. Journal of Development Economics 66, 51-86.

Buchinsky, M. (1998) "Recent Advances in Quantile Regression Models: A Practical Guideline for Empirical Research". The Journal of Human Resources 33, 88-126.

Fernandes, A.M. (2003) "Trade Policy, Trade Volumes and Plant-Level Productivity in Colombian Manufacturing Industries”. Working Paper 3064, The World Bank.

Ferreira, P.C. (2000) "Monopoly Power, Trade Protection and Growth: Cross Industry Evidence”. Ensaios Econômicos da EPGE 381, Fundação Getúlio Vargas.

Goldberg, P. e N. Pavcnik (forthcoming) "Trade, Wages and the Political Economy of Trade Protection: Evidence from the Colombian Trade Reform”. Journal of International Economics.

Hay, D. (2001) “The Post-1990 Brazilian Trade Liberalisation and the Performance of Large Manufacturing Firms: Productivity, Market Share and Profits”. The Economic Journal 111, 620-641.

Harrison, A. (1994) "Productivity, Imperfect Competition and Trade Reform: Theory and Evidence". Journal of International Economics 36, 53-73.

Iscan, T. (1998) "Trade Liberalization and Productivity: A Panel Study of the Mexican Manufacturing Industry”. Journal of Development Studies 34, 123-148.

Kume, H., G. Piani e C.F.B. de Souza (2000) "A Política Brasileira de Importação no Período 1987-98: Descrição e Avaliação". Ipea.

Levinsohn, J. e A. Petrin (2003) "Estimating Production Functions Using Inputs to Control for Unobservables". The Review of Economic Studies 70, 317-342. 
Moreira, M.M. (2000) “A Indústria Brasileira nos Anos 90. O Que Já Se Pode Dizer?”. BNDES.

Muendler, M. (2001) “The Pesquisa Industrial Anual 1986-1998: A Detective's Report”. UC San Diego.

Muendler, M. (2002) "Trade, Technology, and Productivity: a Study of Brazilian Manufacturers, 1986-1998”. UC San Diego.

Olley, G.S. e A. Pakes (1996) "The Dynamics of Productivity in the Telecommunications Equipment Industry”. Econometrica 64, 1263-1297.

Pavcnik, N. (2002) "Trade Liberalization, Exit, and Productivity Improvements: Evidence from Chilean Plants". The Review of Economic Studies 69, 245-276.

Tybout, J.R. (2000) "Manufacturing Firms in Developing Countries: How Well Do They Do, and Why?". Journal of Economic Literature XXXVIII, 11-44.

Tybout, J. R. (2001) “Plant- and Firm-Level Evidence on 'New' Trade Theories”. Working Paper 8418, NBER.

Tybout, J., J. de Melo e V. Corbo (1991) "The Effects of Trade Reforms on Scale and Technical Efficiency: New Evidence from Chile". Journal of International Economics 31, 231-250. 
TABLE 1 - BRAZILIAN MANUFACTURING FIRMS - Pesquisa Industrial Anual (IBGE)

\begin{tabular}{|c|c|c|c|c|c|c|c|c|c|c|c|}
\hline & \multicolumn{2}{|c|}{ Average Tariff } & \multicolumn{2}{|c|}{ Production } & \multicolumn{2}{|c|}{ Workers (Production) } & \multicolumn{2}{|c|}{ Capital } & \multicolumn{2}{|c|}{ Other Inputs } & \multirow[t]{2}{*}{ \# Firms } \\
\hline & final goods & inputs & mean & s.d & mean & s.d & mean & s.d & mean & s.d & \\
\hline \multicolumn{12}{|l|}{ All firms } \\
\hline $87-90$ & $45.9 \%$ & $39.6 \%$ & 62.0 & 334.0 & 683 & 1395 & 19.8 & 165.0 & 22.5 & 139.0 & 4251 \\
\hline $92-94$ & $15.1 \%$ & $13.2 \%$ & 70.8 & 327.0 & 683 & 1373 & 30.2 & 206.0 & 26.5 & 124.0 & 3074 \\
\hline $95-98$ & $15.0 \%$ & $14.7 \%$ & 84.7 & 494.0 & 575 & 1396 & 35.7 & 229.0 & 34.8 & 179.0 & 2765 \\
\hline \multicolumn{12}{|c|}{4 Non-metal mineral products } \\
\hline $87-90$ & $41.0 \%$ & $32.0 \%$ & 33.0 & 47.2 & 709 & 788 & 9.6 & 15.3 & 7.9 & 11.3 & 181 \\
\hline $92-94$ & $10.5 \%$ & $9.7 \%$ & 28.5 & 40.0 & 632 & 735 & 14.7 & 25.2 & 7.7 & 11.6 & 125 \\
\hline 95-98 & $11.9 \%$ & $11.5 \%$ & 24.3 & 37.3 & 394 & 560 & 12.8 & 20.5 & 7.8 & 12.1 & 124 \\
\hline 5 Basic metal & & & & & & & & & & & \\
\hline $87-90$ & $16.0 \%$ & $34.7 \%$ & 248.0 & 488.0 & 1780 & 2763 & 252.0 & 783.0 & 79.7 & 144.0 & 72 \\
\hline $92-94$ & $2.9 \%$ & $12.9 \%$ & 240.0 & 479.0 & 1506 & 2391 & 324.0 & 880.0 & 83.1 & 143.0 & 64 \\
\hline $95-98$ & $5.6 \%$ & $14.3 \%$ & 269.0 & 478.0 & 1459 & 2176 & 367.0 & 805.0 & 111.0 & 188.0 & 59 \\
\hline 6 Non-ferrous & products & & & & & & & & & & \\
\hline $87-90$ & $25.4 \%$ & $35.2 \%$ & 75.9 & 150.0 & 834 & 1257 & 46.5 & 148.0 & 30.0 & 61.3 & 82 \\
\hline $92-94$ & $7.8 \%$ & $12.6 \%$ & 80.9 & 157.0 & 717 & 918 & 58.5 & 154.0 & 31.0 & 64.3 & 67 \\
\hline $95-98$ & $10.0 \%$ & $13.5 \%$ & 96.7 & 191.0 & 645 & 1019 & 75.2 & 158.0 & 46.9 & 89.1 & 56 \\
\hline 7 Metal produc & & & & & & & & & & & \\
\hline $87-90$ & $43.3 \%$ & $36.9 \%$ & 30.9 & 45.1 & 559 & 735 & 8.1 & 15.8 & 7.8 & 12.0 & 78 \\
\hline $92-94$ & $16.8 \%$ & $14.2 \%$ & 30.3 & 46.4 & 542 & 635 & 15.4 & 33.5 & 9.8 & 16.9 & 51 \\
\hline $95-98$ & $17.1 \%$ & $14.8 \%$ & 30.5 & 56.2 & 476 & 752 & 18.2 & 36.9 & 11.3 & 22.7 & 41 \\
\hline 8 Machinery ar & uipment & & & & & & & & & & \\
\hline $87-90$ & $43.0 \%$ & $34.2 \%$ & 62.6 & 113.0 & 932 & 1522 & 15.5 & 27.3 & 17.5 & 33.8 & 295 \\
\hline $92-94$ & $19.4 \%$ & $12.1 \%$ & 60.5 & 125.0 & 765 & 1334 & 20.7 & 45.6 & 18.1 & 50.3 & 230 \\
\hline $95-98$ & $16.7 \%$ & $13.3 \%$ & 48.2 & 85.6 & 479 & 902 & 17.5 & 37.1 & 19.3 & 34.6 & 231 \\
\hline 10 Electrical equ & & & & & & & & & & & \\
\hline $87-90$ & $49.9 \%$ & $35.5 \%$ & 32.3 & 48.5 & 927 & 1172 & 12.6 & 22.0 & 19.7 & 33.0 & 62 \\
\hline $92-94$ & $20.2 \%$ & $14.9 \%$ & 78.7 & 141.0 & 911 & 1183 & 21.7 & 39.0 & 31.9 & 69.8 & 52 \\
\hline $95-98$ & $19.5 \%$ & $15.0 \%$ & 159.0 & 360.0 & 953 & 1479 & 28.7 & 58.8 & 55.5 & 122.0 & 53 \\
\hline 11 Electronic eq & & & & & & & & & & & \\
\hline $87-90$ & $45.4 \%$ & $40.8 \%$ & 38.6 & 70.9 & 576 & 865 & 9.7 & 20.6 & 11.4 & 21.9 & 152 \\
\hline $92-94$ & $21.2 \%$ & $18.4 \%$ & 59.7 & 127.0 & 505 & 793 & 13.2 & 30.0 & 18.5 & 40.9 & 94 \\
\hline $95-98$ & $17.8 \%$ & $16.0 \%$ & 68.8 & 166.0 & 392 & 764 & 15.6 & 36.9 & 27.6 & 70.1 & 80 \\
\hline 12 Automobiles, & is and buses & & & & & & & & & & \\
\hline $87-90$ & $74.1 \%$ & $50.0 \%$ & 336.0 & 905.0 & 2266 & 4929 & 54.1 & 146.0 & 160.0 & 467.0 & 59 \\
\hline $92-94$ & $30.9 \%$ & $20.3 \%$ & 543.0 & 1420.0 & 2848 & 6540 & 78.5 & 204.0 & 270.0 & 778.0 & 38 \\
\hline $95-98$ & $44.8 \%$ & $25.4 \%$ & 990.0 & 2020.0 & 3665 & 6363 & 206.0 & 429.0 & 462.0 & 944.0 & 33 \\
\hline 13 Other Vehicl & $d$ parts & & & & & & & & & & \\
\hline $87-90$ & $44.6 \%$ & $53.7 \%$ & 80.6 & 114.0 & 1372 & 1454 & 19.7 & 30.5 & 26.7 & 38.5 & 112 \\
\hline $92-94$ & $18.6 \%$ & $22.1 \%$ & 87.1 & 105.0 & 1161 & 1178 & 31.0 & 43.5 & 29.3 & 35.1 & 93 \\
\hline $95-98$ & $17.8 \%$ & $29.3 \%$ & 105.0 & 137.0 & 900 & 1130 & 30.6 & 39.3 & 38.1 & 51.7 & 100 \\
\hline 14 Wood and fu & & & & & & & & & & & \\
\hline $87-90$ & $32.1 \%$ & $31.9 \%$ & 17.6 & 27.8 & 481 & 692 & 2.8 & 7.2 & 6.3 & 12.0 & 221 \\
\hline $92-94$ & $9.3 \%$ & $10.6 \%$ & 20.3 & 27.9 & 567 & 816 & 5.2 & 9.5 & 8.3 & 12.2 & 118 \\
\hline $95-98$ & $12.3 \%$ & $12.6 \%$ & 17.3 & 22.8 & 336 & 492 & 5.0 & 7.5 & 8.2 & 12.1 & 104 \\
\hline 15 Paper, pulp & ardboard & & & & & & & & & & \\
\hline 87-90 & $35.1 \%$ & $32.2 \%$ & 67.0 & 97.9 & 796 & 837 & 34.4 & 78.7 & 24.6 & 34.4 & 127 \\
\hline $92-94$ & $9.0 \%$ & $9.6 \%$ & 79.5 & 126.0 & 867 & 998 & 65.4 & 134.0 & 28.4 & 45.5 & 90 \\
\hline 95-98 & $12.1 \%$ & $11.7 \%$ & 70.8 & 114.0 & 547 & 748 & 49.6 & 98.7 & 27.2 & 41.4 & 97 \\
\hline 16 Rubber prod & & & & & & & & & & & \\
\hline $87-90$ & $55.9 \%$ & $49.1 \%$ & 72.4 & 208.0 & 560 & 931 & 9.9 & 28.0 & 21.5 & 73.5 & 122 \\
\hline $92-94$ & $16.0 \%$ & $15.7 \%$ & 70.8 & 163.0 & 746 & 1095 & 16.9 & 38.7 & 22.3 & 60.6 & 78 \\
\hline 95-98 & $13.5 \%$ & $16.1 \%$ & 69.7 & 175.0 & 571 & 905 & 20.0 & 35.8 & 27.5 & 73.0 & 66 \\
\hline 17 Non-petroch & I chemical ele & hents & & & & & & & & & \\
\hline $87-90$ & $38.6 \%$ & $32.1 \%$ & 57.2 & 77.1 & 640 & 813 & 26.7 & 40.7 & 25.4 & 29.5 & 145 \\
\hline $92-94$ & $12.0 \%$ & $9.7 \%$ & 66.6 & 73.9 & 626 & 736 & 30.4 & 36.6 & 32.5 & 36.6 & 117 \\
\hline 95-98 & $13.8 \%$ & $12.0 \%$ & 57.2 & 76.0 & 489 & 739 & 34.5 & 51.7 & 26.3 & 30.1 & 117 \\
\hline 18 Basic petroc & al products & & & & & & & & & & \\
\hline $87-90$ & $26.2 \%$ & $32.7 \%$ & 308.0 & 1770.0 & 878 & 4317 & 129.0 & 725.0 & 114.0 & 741.0 & 108 \\
\hline $92-94$ & $9.5 \%$ & $10.9 \%$ & 234.0 & 1420.0 & 657 & 3249 & 146.0 & 863.0 & 79.7 & 412.0 & 89 \\
\hline 95-98 & $8.5 \%$ & $10.6 \%$ & 453.0 & 2520.0 & 897 & 4111 & 205.0 & 1140.0 & 149.0 & 762.0 & 63 \\
\hline 19 Chemical pro & & & & & & & & & & & \\
\hline $87-90$ & $37.5 \%$ & $33.7 \%$ & 73.4 & 123.0 & 392 & 512 & 16.9 & 42.2 & 27.5 & 46.0 & 190 \\
\hline $92-94$ & $13.6 \%$ & $10.8 \%$ & 84.5 & 128.0 & 446 & 705 & 28.5 & 67.9 & 30.4 & 44.5 & 142 \\
\hline 95-98 & $10.8 \%$ & $12.6 \%$ & 88.7 & 158.0 & 352 & 507 & 26.6 & 49.0 & 41.6 & 69.9 & 122 \\
\hline 20 Pharmaceuti & oducts and $p$ & fume & & & & & & & & & \\
\hline $87-90$ & $46.6 \%$ & $38.9 \%$ & 59.9 & 94.6 & 220 & 250 & 6.1 & 11.6 & 9.8 & 19.2 & 127 \\
\hline $92-94$ & $10.2 \%$ & $9.0 \%$ & 54.7 & 81.8 & 237 & 244 & 10.8 & 18.2 & 10.1 & 15.9 & 109 \\
\hline $95-98$ & $9.2 \%$ & $20.8 \%$ & 59.5 & 94.5 & 198 & 216 & 14.4 & 22.2 & 17.4 & 30.1 & 99 \\
\hline
\end{tabular}

Production, capital stock and other inputs: 1,000,000 reais as of August 1994. 
TABLE 1 - BRAZILIAN MANUFACTURING FIRMS - Pesquisa Industrial Anual (IBGE) (continuation)

\begin{tabular}{|c|c|c|c|c|c|c|c|c|c|c|c|}
\hline & \multicolumn{2}{|c|}{ Average Tariff } & \multicolumn{2}{|c|}{ Production } & \multicolumn{2}{|c|}{ Workers (Production) } & \multicolumn{2}{|c|}{ Capital } & \multicolumn{2}{|c|}{ Other Inputs } & \multirow[t]{2}{*}{ \# Firms } \\
\hline & final goods & inputs & mean & s.d & mean & s.d & mean & s.d & mean & s.d & \\
\hline \multicolumn{12}{|l|}{21 Plastics } \\
\hline $87-90$ & $43.4 \%$ & $38.2 \%$ & 33.5 & 54.5 & 589 & 821 & 6.6 & 14.4 & 10.2 & 17.1 & 204 \\
\hline $92-94$ & $17.2 \%$ & $14.2 \%$ & 40.2 & 64.2 & 685 & 493 & 11.2 & 21.6 & 11.7 & 17.8 & 142 \\
\hline $95-98$ & $16.5 \%$ & $15.5 \%$ & 31.5 & 54.7 & 405 & 605 & 14.3 & 25.5 & 12.1 & 20.2 & 137 \\
\hline \multicolumn{12}{|l|}{22 Textiles } \\
\hline $87-90$ & $62.9 \%$ & $60.9 \%$ & 28.8 & 47.5 & 732 & 1037 & 9.8 & 22.2 & 9.9 & 18.8 & 471 \\
\hline $92-94$ & $17.6 \%$ & $18.5 \%$ & 41.7 & 63.0 & 774 & 933 & 15.0 & 26.1 & 14.6 & 24.6 & 302 \\
\hline 95-98 & $17.2 \%$ & $16.4 \%$ & 35.1 & 58.1 & 594 & 846 & 17.3 & 30.0 & 14.9 & 24.2 & 261 \\
\hline \multicolumn{12}{|l|}{23 Apparel } \\
\hline 87-90 & $76.0 \%$ & $42.3 \%$ & 19.8 & 38.0 & 872 & 1451 & 3.6 & 8.6 & 7.3 & 14.6 & 290 \\
\hline $92-94$ & $22.8 \%$ & $14.5 \%$ & 28.1 & 56.8 & 807 & 1240 & 6.7 & 16.9 & 9.1 & 18.0 & 190 \\
\hline $95-98$ & $21.1 \%$ & $15.5 \%$ & 27.7 & 56.4 & 541 & 866 & 6.7 & 15.9 & 8.6 & 16.5 & 162 \\
\hline \multicolumn{12}{|c|}{24 Leather Products and footware } \\
\hline $87-90$ & $44.0 \%$ & $44.7 \%$ & 31.4 & 41.3 & 529 & 647 & 4.1 & 4.9 & 11.0 & 16.9 & 93 \\
\hline $92-94$ & $14.5 \%$ & $14.7 \%$ & 29.1 & 40.3 & 492 & 602 & 6.6 & 10.2 & 12.6 & 20.4 & 76 \\
\hline $95-98$ & $17.1 \%$ & $17.1 \%$ & 14.3 & 19.6 & 266 & 376 & 7.0 & 9.7 & 7.3 & 11.2 & 60 \\
\hline \multicolumn{12}{|c|}{25 Coffee products } \\
\hline $87-90$ & $41.0 \%$ & $40.3 \%$ & 17.0 & 26.7 & 101 & 148 & 2.4 & 5.2 & 7.2 & 13.4 & 129 \\
\hline $92-94$ & $12.1 \%$ & $11.8 \%$ & 17.2 & 24.0 & 84 & 96 & 3.3 & 6.5 & 8.6 & 15.3 & 90 \\
\hline $95-98$ & $12.2 \%$ & $11.9 \%$ & 19.8 & 30.2 & 91 & 126 & 4.5 & 6.3 & 11.4 & 17.1 & 80 \\
\hline \multicolumn{12}{|c|}{26 Processed edible products } \\
\hline $87-90$ & $34.7 \%$ & $45.1 \%$ & 58.2 & 271.0 & 252 & 575 & 5.9 & 11.4 & 19.7 & 27.8 & 151 \\
\hline $92-94$ & $9.8 \%$ & $14.3 \%$ & 69.8 & 340.0 & 241 & 487 & 13.1 & 38.7 & 23.2 & 41.5 & 125 \\
\hline $95-98$ & $13.3 \%$ & $14.4 \%$ & 95.0 & 375.0 & 288 & 648 & 18.8 & 64.7 & 34.6 & 74.4 & 100 \\
\hline \multicolumn{12}{|c|}{27 Meat and Poultry } \\
\hline $87-90$ & $28.8 \%$ & $32.9 \%$ & 60.5 & 117.0 & 656 & 1172 & 9.3 & 20.8 & 31.3 & 55.2 & 186 \\
\hline $92-94$ & $9.1 \%$ & $10.3 \%$ & 78.5 & 148.0 & 876 & 1511 & 20.9 & 45.1 & 45.2 & 76.2 & 129 \\
\hline $95-98$ & $10.3 \%$ & $12.2 \%$ & 78.0 & 165.0 & 883 & 1807 & 20.0 & 36.1 & 44.9 & 88.4 & 108 \\
\hline \multicolumn{12}{|c|}{28 Processed dairy products } \\
\hline $87-90$ & $45.0 \%$ & $42.4 \%$ & 97.8 & 326.0 & 433 & 775 & 8.5 & 24.1 & 47.0 & 114.0 & 99 \\
\hline $92-94$ & $18.8 \%$ & $20.5 \%$ & 96.7 & 319.0 & 461 & 879 & 14.7 & 44.3 & 43.4 & 91.3 & 82 \\
\hline $95-98$ & $16.5 \%$ & $19.1 \%$ & 114.0 & 351.0 & 493 & 1259 & 29.5 & 76.3 & 50.5 & 128.0 & 72 \\
\hline \multicolumn{12}{|l|}{29 Sugar } \\
\hline $87-90$ & $39.9 \%$ & $39.7 \%$ & 50.4 & 73.4 & 906 & 746 & 24.8 & 21.8 & 24.7 & 39.0 & 72 \\
\hline $92-94$ & $16.6 \%$ & $15.1 \%$ & 56.4 & 78.9 & 977 & 979 & 31.4 & 22.9 & 26.7 & 38.3 & 60 \\
\hline 95-98 & $17.4 \%$ & $16.0 \%$ & 55.6 & 91.7 & 826 & 1111 & 31.1 & 23.3 & 29.1 & 59.5 & 60 \\
\hline \multicolumn{12}{|l|}{30 Vegetable oil } \\
\hline $87-90$ & $27.8 \%$ & $34.5 \%$ & 91.8 & 179.0 & 321 & 577 & 18.2 & 38.9 & 53.1 & 102.0 & 77 \\
\hline $92-94$ & $8.7 \%$ & $10.7 \%$ & 95.7 & 212.0 & 422 & 1135 & 35.0 & 84.5 & 54.9 & 119.0 & 52 \\
\hline $95-98$ & $9.6 \%$ & $13.5 \%$ & 144.0 & 378.0 & 671 & 2222 & 42.9 & 132.0 & 92.7 & 240.0 & 44 \\
\hline \multicolumn{12}{|c|}{31 Beverage and other food products } \\
\hline $87-90$ & $57.4 \%$ & $27.5 \%$ & 51.2 & 130.0 & 481 & 663 & 9.4 & 22.5 & 13.4 & 23.4 & 346 \\
\hline $92-94$ & $18.2 \%$ & $7.9 \%$ & 56.8 & 113.0 & 521 & 638 & 18.6 & 40.2 & 15.9 & 27.8 & 269 \\
\hline $95-98$ & $16.2 \%$ & $9.0 \%$ & 67.6 & 155.0 & 450 & 594 & 26.8 & 70.9 & 22.3 & 46.2 & 236 \\
\hline
\end{tabular}

Production, capital stock and other inputs: 1,000,000 reais as of August 1994. 
TABLE 2 - ESTIMATED PRODUCTION FUNCTIONS

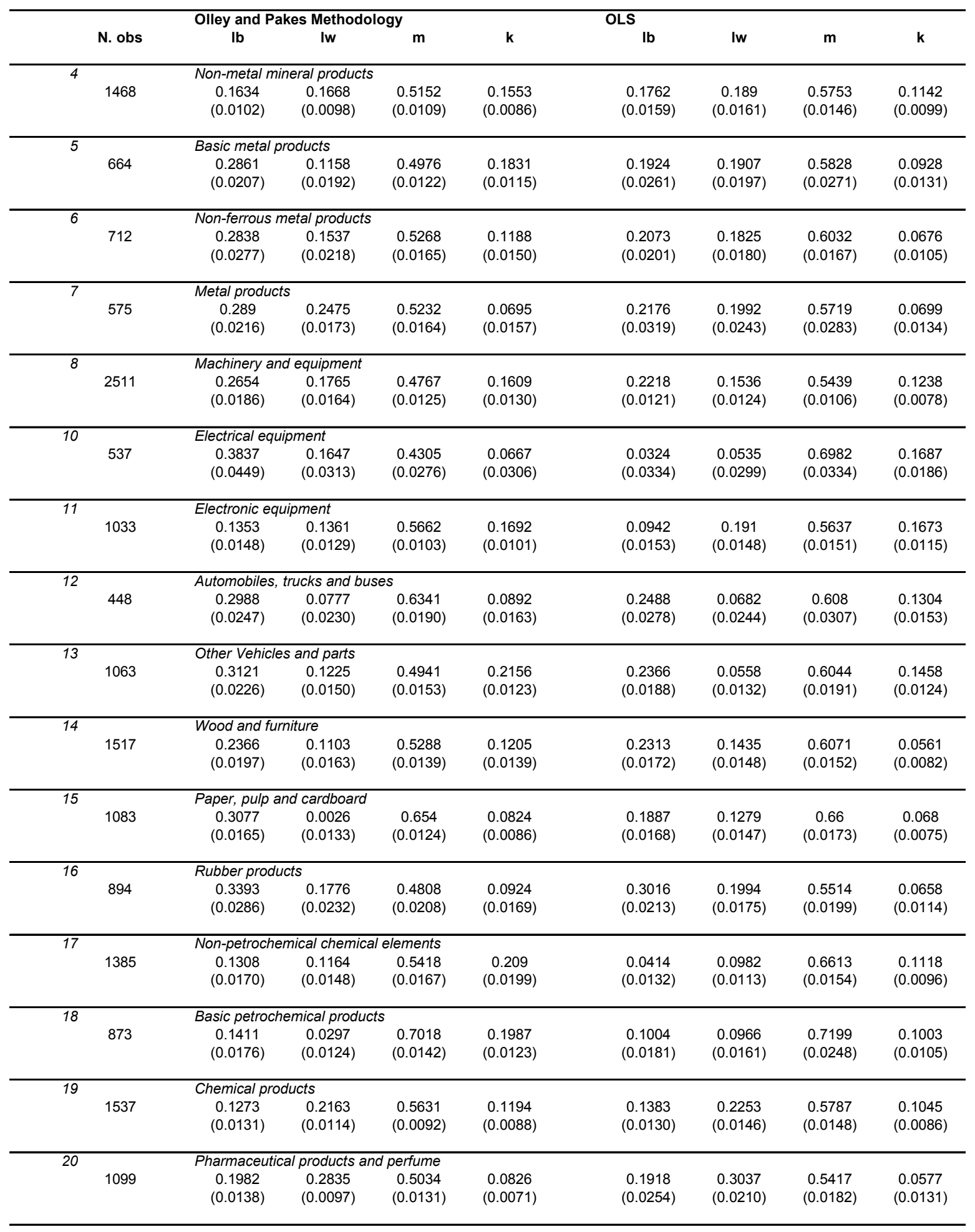


TABLE 2 - ESTIMATED PRODUCTION FUNCTIONS (continuation)

\begin{tabular}{|c|c|c|c|c|c|c|c|c|c|}
\hline & \multicolumn{4}{|c|}{ Olley and Pakes Methodology } & \multicolumn{3}{|c|}{ OLS } & \multirow[b]{2}{*}{$\mathrm{m}$} & \multirow[b]{2}{*}{ k } \\
\hline & N. obs & Ib & Iw & $\mathbf{m}$ & $\mathbf{k}$ & lb & Iw & & \\
\hline \multirow[t]{2}{*}{21} & & Plastics & & & & & & & \\
\hline & 1585 & $\begin{array}{c}0.1585 \\
(0.0155)\end{array}$ & $\begin{array}{c}0.1924 \\
(0.0118)\end{array}$ & $\begin{array}{c}0.5537 \\
(0.0096)\end{array}$ & $\begin{array}{c}0.1253 \\
(0.0076)\end{array}$ & $\begin{array}{c}0.1735 \\
(0.0154)\end{array}$ & $\begin{array}{c}0.1897 \\
(0.0130)\end{array}$ & $\begin{array}{c}0.5766 \\
(0.0143)\end{array}$ & $\begin{array}{c}0.1023 \\
(0.0082)\end{array}$ \\
\hline \multirow[t]{2}{*}{22} & & Textiles & & & & & & & \\
\hline & 3526 & $\begin{array}{c}0.2052 \\
(0.0049)\end{array}$ & $\begin{array}{c}0.1437 \\
(0.0041)\end{array}$ & $\begin{array}{c}0.5581 \\
(0.0034)\end{array}$ & $\begin{array}{c}0.1028 \\
(0.0027)\end{array}$ & $\begin{array}{c}0.1854 \\
(0.0086)\end{array}$ & $\begin{array}{c}0.1898 \\
(0.0093)\end{array}$ & $\begin{array}{c}0.5788 \\
(0.0082)\end{array}$ & $\begin{array}{r}0.0735 \\
(0.0054)\end{array}$ \\
\hline \multirow[t]{2}{*}{23} & & Apparel & & & & & & & \\
\hline & 2187 & $\begin{array}{c}0.2104 \\
(0.0154)\end{array}$ & $\begin{array}{c}0.1707 \\
(0.0138)\end{array}$ & $\begin{array}{c}0.5225 \\
(0.0124)\end{array}$ & $\begin{array}{c}0.1823 \\
(0.0119)\end{array}$ & $\begin{array}{c}0.1816 \\
(0.0121)\end{array}$ & $\begin{array}{c}0.1494 \\
(0.0110)\end{array}$ & $\begin{array}{c}0.5701 \\
(0.0122)\end{array}$ & $\begin{array}{c}0.1392 \\
(0.0077)\end{array}$ \\
\hline \multirow[t]{2}{*}{24} & \multicolumn{4}{|c|}{ Leather Products and footware } & & & & & \\
\hline & 777 & $\begin{array}{c}0.3103 \\
(0.0110)\end{array}$ & $\begin{array}{c}0.1937 \\
(0.0091)\end{array}$ & $\begin{array}{c}0.5153 \\
(0.0082)\end{array}$ & $\begin{array}{c}0.0761 \\
(0.0098)\end{array}$ & $\begin{array}{c}0.2933 \\
(0.0242)\end{array}$ & $\begin{array}{c}0.1421 \\
(0.0172)\end{array}$ & $\begin{array}{c}0.6044 \\
(0.0188)\end{array}$ & $\begin{array}{c}0.014 \\
(0.0103)\end{array}$ \\
\hline \multirow[t]{2}{*}{25} & \multicolumn{3}{|c|}{ Coffee products } & & & & & & \\
\hline & 920 & $\begin{array}{c}0.2006 \\
(0.0174)\end{array}$ & $\begin{array}{c}0.1017 \\
(0.0156)\end{array}$ & $\begin{array}{c}0.5729 \\
(0.0131)\end{array}$ & $\begin{array}{c}0.1326 \\
(0.0138)\end{array}$ & $\begin{array}{c}0.1765 \\
(0.0180)\end{array}$ & $\begin{array}{c}0.1708 \\
(0.0159)\end{array}$ & $\begin{array}{c}0.6368 \\
(0.0204)\end{array}$ & $\begin{array}{c}0.0562 \\
(0.0140)\end{array}$ \\
\hline \multirow[t]{2}{*}{26} & \multicolumn{4}{|c|}{ Processed edible products } & & & & & \\
\hline & 1230 & $\begin{array}{c}0.2487 \\
(0.0123)\end{array}$ & $\begin{array}{c}0.1335 \\
(0.0108)\end{array}$ & $\begin{array}{c}0.6263 \\
(0.0077)\end{array}$ & $\begin{array}{c}0.0861 \\
(0.0087)\end{array}$ & $\begin{array}{c}0.2717 \\
(0.0211)\end{array}$ & $\begin{array}{c}0.1534 \\
(0.0183)\end{array}$ & $\begin{array}{c}0.6164 \\
(0.0183)\end{array}$ & $\begin{array}{c}0.0811 \\
(0.0120)\end{array}$ \\
\hline \multirow[t]{2}{*}{27} & \multicolumn{3}{|c|}{ Meat and Poultry } & & & & & & \\
\hline & 1393 & $\begin{array}{c}0.3656 \\
(0.0110)\end{array}$ & $\begin{array}{c}0.087 \\
(0.0091)\end{array}$ & $\begin{array}{c}0.5745 \\
(0.0068)\end{array}$ & $\begin{array}{c}0.0527 \\
(0.0062)\end{array}$ & $\begin{array}{c}0.2752 \\
(0.0175)\end{array}$ & $\begin{array}{c}0.0827 \\
(0.0086)\end{array}$ & $\begin{array}{c}0.6471 \\
(0.0156)\end{array}$ & $\begin{array}{r}0.0303 \\
(0.0076)\end{array}$ \\
\hline \multirow[t]{2}{*}{28} & \multicolumn{4}{|c|}{ Processed dairy products } & & & & & \\
\hline & 855 & $\begin{array}{c}0.3525 \\
(0.0210)\end{array}$ & $\begin{array}{c}0.1696 \\
(0.0191)\end{array}$ & $\begin{array}{c}0.4752 \\
(0.0137)\end{array}$ & $\begin{array}{c}0.1472 \\
(0.0135)\end{array}$ & $\begin{array}{c}0.3526 \\
(0.0215)\end{array}$ & $\begin{array}{c}0.1721 \\
(0.0164)\end{array}$ & $\begin{array}{c}0.5678 \\
(0.0218)\end{array}$ & $\begin{array}{r}0.0309 \\
(0.0100)\end{array}$ \\
\hline \multirow[t]{2}{*}{29} & & Sugar & & & & & & & \\
\hline & 725 & $\begin{array}{c}0.1409 \\
(0.0111)\end{array}$ & $\begin{array}{c}0.128 \\
(0.0106)\end{array}$ & $\begin{array}{c}0.6302 \\
(0.0103)\end{array}$ & $\begin{array}{c}0.0992 \\
(0.0145)\end{array}$ & $\begin{array}{c}0.1359 \\
(0.0174)\end{array}$ & $\begin{array}{c}0.1242 \\
(0.0123)\end{array}$ & $\begin{array}{c}0.6821 \\
(0.0205)\end{array}$ & $\begin{array}{c}0.0462 \\
(0.0138)\end{array}$ \\
\hline \multirow[t]{2}{*}{30} & & Vegetable oil & & & & & & & \\
\hline & 551 & $\begin{array}{c}0.1474 \\
(0.0240)\end{array}$ & $\begin{array}{c}0.027 \\
(0.0168)\end{array}$ & $\begin{array}{c}0.6475 \\
(0.0102)\end{array}$ & $\begin{array}{c}0.1541 \\
(0.0173)\end{array}$ & $\begin{array}{c}0.198 \\
(0.0247)\end{array}$ & $\begin{array}{c}0.0858 \\
(0.0206)\end{array}$ & $\begin{array}{c}0.6983 \\
(0.0219)\end{array}$ & $\begin{array}{c}0.0652 \\
(0.0151)\end{array}$ \\
\hline \multirow[t]{2}{*}{31} & \multicolumn{5}{|c|}{ Beverage and other food products } & & & & \\
\hline & 2818 & $\begin{array}{c}0.19 \\
(0.0079)\end{array}$ & $\begin{array}{c}0.0956 \\
(0.0068)\end{array}$ & $\begin{array}{c}0.608 \\
(0.0079)\end{array}$ & $\begin{array}{c}0.1517 \\
(0.0048)\end{array}$ & $\begin{array}{c}0.1165 \\
(0.0135)\end{array}$ & $\begin{array}{c}0.1618 \\
(0.0098)\end{array}$ & $\begin{array}{c}0.634 \\
(0.0147)\end{array}$ & $\begin{array}{r}0.1422 \\
(0.0077)\end{array}$ \\
\hline
\end{tabular}


TABLE 3 - TOTAL FACTOR PRODUCTIVITY (1986 = 100)

\begin{tabular}{|c|c|c|c|c|c|c|}
\hline & 1986 & 1987 & 1988 & 1989 & 1990 & 1992 \\
\hline 4 Non-metal mineral products & 100.00 & 80.97 & 86.62 & 77.86 & 83.97 & 65.53 \\
\hline 5 Basic metal products & 100.00 & 111.11 & 133.24 & 134.21 & 131.93 & 124.28 \\
\hline 6 Non-ferrous metal products & 100.00 & 121.11 & 130.97 & 133.01 & 120.26 & 130.96 \\
\hline 7 Metal products & 100.00 & 116.43 & 132.52 & 134.83 & 129.37 & 112.55 \\
\hline 8 Machinery and equipment & 100.00 & 102.56 & 94.91 & 98.18 & 86.20 & 94.92 \\
\hline 10 Electrical equipment & 100.00 & 124.49 & 112.59 & 133.36 & 141.32 & 201.63 \\
\hline 11 Electronic equipment & 100.00 & 120.39 & 135.47 & 147.00 & 120.07 & 148.11 \\
\hline 12 Automobiles, trucks and buses & 100.00 & 95.48 & 111.06 & 116.95 & 93.62 & 107.32 \\
\hline 13 Other Vehicles and parts & 100.00 & 122.37 & 132.09 & 141.57 & 109.91 & 116.86 \\
\hline 14 Wood and furniture & 100.00 & 87.10 & 87.99 & 81.84 & 64.02 & 61.85 \\
\hline 15 Paper, pulp and cardboard & 100.00 & 111.48 & 110.29 & 113.08 & 108.58 & 111.16 \\
\hline 16 Rubber products & 100.00 & 113.20 & 133.28 & 161.48 & 136.86 & 120.91 \\
\hline 17 Non-petrochemical chemical elements & 100.00 & 103.81 & 114.35 & 118.55 & 101.65 & 104.91 \\
\hline 18 Basic petrochemical products & 100.00 & 95.31 & 93.78 & 89.37 & 76.51 & 71.19 \\
\hline 19 Chemical products & 100.00 & 107.46 & 129.66 & 142.38 & 123.55 & 123.31 \\
\hline 20 Pharmaceutical products and perfume & 100.00 & 120.99 & 115.69 & 132.25 & 114.81 & 99.36 \\
\hline 21 Plastics & 100.00 & 121.27 & 109.26 & 113.49 & 104.14 & 115.12 \\
\hline 22 Textiles & 100.00 & 110.05 & 119.41 & 117.21 & 113.11 & 115.80 \\
\hline 23 Apparel & 100.00 & 104.96 & 99.31 & 57.02 & 53.24 & 90.01 \\
\hline 24 Leather Products and footware & 100.00 & 102.59 & 90.21 & 86.16 & 77.65 & 75.69 \\
\hline 25 Coffee products & 100.00 & 144.73 & 158.48 & 139.39 & 118.22 & 128.08 \\
\hline 26 Processed edible products & 100.00 & 70.41 & 67.48 & 61.63 & 69.46 & 66.10 \\
\hline 27 Meat and Poultry & 100.00 & 108.46 & 108.66 & 98.87 & 106.48 & 93.74 \\
\hline 28 Processed dairy products & 100.00 & 95.45 & 103.03 & 96.77 & 82.26 & 81.05 \\
\hline 29 Sugar & 100.00 & 111.40 & 120.61 & 128.66 & 115.98 & 117.28 \\
\hline 30 Vegetable oil & 100.00 & 113.33 & 110.44 & 122.73 & 118.35 & 97.61 \\
\hline 31 Beverage and other food products & 100.00 & 99.60 & 127.70 & 125.02 & 110.88 & 98.06 \\
\hline
\end{tabular}

TABLE 3 - TOTAL FACTOR PRODUCTIVITY (1986 = 100) (continuation)

\begin{tabular}{|c|c|c|c|c|c|c|}
\hline & 1993 & 1994 & 1995 & 1996 & 1997 & 1998 \\
\hline 4 Non-metal mineral products & 77.40 & 58.47 & 43.32 & 67.03 & 66.35 & 63.70 \\
\hline 5 Basic metal products & 126.49 & 120.16 & 110.28 & 122.90 & 132.69 & 134.22 \\
\hline 6 Non-ferrous metal products & 152.65 & 125.25 & 120.05 & 122.95 & 133.40 & 133.72 \\
\hline 7 Metal products & 106.04 & 103.18 & 107.98 & 110.48 & 123.02 & 134.24 \\
\hline 8 Machinery and equipment & 111.29 & 97.16 & 71.49 & 93.96 & 105.19 & 110.65 \\
\hline 10 Electrical equipment & 212.83 & 216.56 & 210.92 & 225.42 & 237.19 & 245.96 \\
\hline 11 Electronic equipment & 171.17 & 152.08 & 148.61 & 161.90 & 218.84 & 200.67 \\
\hline 12 Automobiles, trucks and buses & 123.05 & 126.81 & 101.50 & 117.58 & 123.42 & 130.10 \\
\hline 13 Other Vehicles and parts & 147.20 & 137.72 & 136.26 & 147.96 & 160.98 & 163.05 \\
\hline 14 Wood and furniture & 68.13 & 71.37 & 58.77 & 72.81 & 75.81 & 81.13 \\
\hline 15 Paper, pulp and cardboard & 114.49 & 111.63 & 101.12 & 123.73 & 122.80 & 132.48 \\
\hline 16 Rubber products & 122.92 & 103.53 & 96.15 & 108.12 & 116.27 & 127.54 \\
\hline 17 Non-petrochemical chemical elements & 107.20 & 107.00 & 100.08 & 112.93 & 111.03 & 116.20 \\
\hline 18 Basic petrochemical products & 88.95 & 78.38 & 65.09 & 70.83 & 74.44 & 85.77 \\
\hline 19 Chemical products & 134.46 & 124.10 & 125.28 & 144.62 & 139.86 & 140.04 \\
\hline 20 Pharmaceutical products and perfume & 96.67 & 83.88 & 70.48 & 73.03 & 63.82 & 56.91 \\
\hline 21 Plastics & 119.62 & 99.97 & 88.35 & 103.67 & 105.71 & 107.20 \\
\hline 22 Textiles & 129.32 & 110.97 & 99.50 & 103.65 & 110.18 & 112.14 \\
\hline 23 Apparel & 107.00 & 121.01 & 117.25 & 106.75 & 119.02 & 130.54 \\
\hline 24 Leather Products and footware & 77.86 & 61.72 & 47.09 & 62.89 & 70.72 & 72.58 \\
\hline 25 Coffee products & 127.21 & 103.49 & 97.01 & 96.29 & 94.10 & 114.84 \\
\hline 26 Processed edible products & 76.86 & 73.06 & 63.97 & 67.80 & 137.06 & 140.44 \\
\hline 27 Meat and Poultry & 92.75 & 89.97 & 84.24 & 101.56 & 96.52 & 91.46 \\
\hline 28 Processed dairy products & 85.86 & 72.36 & 68.07 & 78.88 & 83.12 & 79.60 \\
\hline 29 Sugar & 129.65 & 127.99 & 119.74 & 125.32 & 141.09 & 137.31 \\
\hline 30 Vegetable oil & 109.04 & 109.85 & 95.21 & 137.70 & 147.29 & 140.43 \\
\hline 31 Beverage and other food products & 99.27 & 85.81 & 74.19 & 82.96 & 77.37 & 89.68 \\
\hline
\end{tabular}


TABLE 4 - EFFECT OF NOMINAL TARIFF ON LOG OF PRODUCTIVITY

\begin{tabular}{|c|c|c|c|c|}
\hline Dependent Variable & Nominal Tariff & Year Effects & Industry Effects & Firm Effects \\
\hline In productivity & $\begin{array}{c}0.3914 \\
(0.0322)^{\star * \star}\end{array}$ & yes & no & no \\
\hline In productivity & $\begin{array}{l}-0.0042 \\
(0.0424)\end{array}$ & yes & yes & no \\
\hline In productivity & $\begin{array}{c}-0.1343 \\
(0.0338)^{* * *}\end{array}$ & yes & yes & yes \\
\hline $\begin{array}{l}\text { In productivity } \quad \mathrm{n}=23589 \\
\text { (estimated using OLS) }\end{array}$ & $\begin{array}{c}-0.0847 \\
(0.0339)^{\star \star *}\end{array}$ & yes & yes & yes \\
\hline
\end{tabular}

Robust standard errors into parenthesis.

$* * *, * *, *$ : significant at $1 \%, 5 \%$ and $10 \%$, respectively.

TABLE 5 - EFFECT OF NOMINAL TARIFF AND TARIFFS ON INPUTS ON LOG OF PRODUCTIVITY

\begin{tabular}{|c|c|c|c|c|c|}
\hline Dependent Variable & Nominal Tariff & Tariffs on Inputs & Year Effects & Industry Effects & Firm Effects \\
\hline In productivity & $\begin{array}{c}0.2792 \\
(0.0379)^{\star * *}\end{array}$ & $\begin{array}{c}0.4343 \\
(0.0565)^{\star * *}\end{array}$ & yes & no & no \\
\hline In productivity & $\begin{array}{c}0.0472 \\
(0.0457)\end{array}$ & $\begin{array}{c}-0.2712 \\
(0.0727)^{\star \star *}\end{array}$ & yes & yes & no \\
\hline In productivity & $\begin{array}{c}-0.0947 \\
(0.0363)^{\star * *}\end{array}$ & $\begin{array}{c}-0.1531 \\
(0.0516)^{\star * *}\end{array}$ & yes & yes & yes \\
\hline $\begin{array}{l}\text { In productivity } \mathrm{n}=23589 \\
\text { (estimated using OLS) }\end{array}$ & $\begin{array}{l}-0.0432 \\
(0.0364)\end{array}$ & $\begin{array}{c}-0.1603 \\
(0.0517)^{\star * *}\end{array}$ & yes & yes & yes \\
\hline
\end{tabular}

Robust standard errors into parenthesis.

$* * *, * *, *$ : significant at $1 \%, 5 \%$ and $10 \%$, respectively. 
TABLE 6 - FIRM'S CHARACTERISTICS BY SECTOR

\begin{tabular}{|c|c|c|c|c|c|c|}
\hline industry & initial tariff & initial import share & initial export share & type of industry & factor intensity & initial herfindahl \\
\hline 4 & $39.2 \%$ & $1.0 \%$ & $2.0 \%$ & intermediate & natural resources & 0.0171 \\
\hline 5 & $29.0 \%$ & $1.5 \%$ & $16.8 \%$ & intermediate & capital & 0.0772 \\
\hline 6 & $30.6 \%$ & $4.9 \%$ & $17.5 \%$ & intermediate & natural resources & 0.0627 \\
\hline 7 & $45.8 \%$ & $1.1 \%$ & $3.1 \%$ & intermediate & capital & 0.0426 \\
\hline 8 & $46.8 \%$ & $6.7 \%$ & $9.0 \%$ & capital & technology & 0.0159 \\
\hline 10 & $50.0 \%$ & $11.4 \%$ & $6.2 \%$ & capital & technology & 0.0685 \\
\hline 11 & $48.6 \%$ & $14.4 \%$ & $7.6 \%$ & consumer & technology & 0.0322 \\
\hline 12 & $65.0 \%$ & $0.3 \%$ & $13.6 \%$ & transport equipment & technology & 0.1438 \\
\hline 13 & $42.8 \%$ & $9.0 \%$ & $15.0 \%$ & transport equipment & technology & 0.0271 \\
\hline 14 & $30.3 \%$ & $0.4 \%$ & $4.6 \%$ & consumer & natural resources & 0.0183 \\
\hline 15 & $32.1 \%$ & $1.9 \%$ & $5.9 \%$ & intermediate & natural resources & 0.0256 \\
\hline 16 & $49.3 \%$ & $3.8 \%$ & $5.7 \%$ & intermediate & technology & 0.1343 \\
\hline 17 & $31.4 \%$ & $12.3 \%$ & $5.4 \%$ & intermediate & capital & 0.0187 \\
\hline 18 & $33.8 \%$ & $4.1 \%$ & $9.4 \%$ & intermediate & capital & 0.4212 \\
\hline 19 & $34.7 \%$ & $5.9 \%$ & $2.5 \%$ & intermediate & capital & 0.0220 \\
\hline 20 & $45.3 \%$ & $5.0 \%$ & $1.7 \%$ & consumer & labor & 0.0330 \\
\hline 21 & $57.1 \%$ & $1.8 \%$ & $2.6 \%$ & intermediate & labor & 0.0211 \\
\hline 22 & $57.3 \%$ & $1.6 \%$ & $5.6 \%$ & intermediate & labor & 0.0086 \\
\hline 23 & $76.0 \%$ & $0.3 \%$ & $1.5 \%$ & consumer & labor & 0.0172 \\
\hline 24 & $41.0 \%$ & $2.7 \%$ & $25.2 \%$ & intermediate & labor & 0.0311 \\
\hline 25 & $35.0 \%$ & $0.0 \%$ & $35.0 \%$ & consumer & natural resources & 0.0326 \\
\hline 26 & $42.0 \%$ & $2.8 \%$ & $7.3 \%$ & consumer & natural resources & 0.0239 \\
\hline 27 & $29.8 \%$ & $1.0 \%$ & $9.5 \%$ & consumer & natural resources & 0.0294 \\
\hline 28 & $40.3 \%$ & $1.8 \%$ & $0.0 \%$ & consumer & natural resources & 0.1099 \\
\hline 29 & $29.3 \%$ & $0.0 \%$ & $13.1 \%$ & consumer & natural resources & 0.0409 \\
\hline 30 & $20.5 \%$ & $1.4 \%$ & $25.2 \%$ & intermediate & natural resources & 0.0693 \\
\hline 31 & $51.8 \%$ & $2.5 \%$ & $2.4 \%$ & consumer & natural resources & 0.0175 \\
\hline
\end{tabular}

Initial import share, initial export share and type of industry are classified by nivel 80 - here grouped by nivel 50 just for simplicity

Factor intensity is classified by nivel 100 - here grouped by nivel 50 just for simplicity 
TABLE 7 - PRODUCTIVITY AND TARIFFS - MARGINAL EFFECTS

Dependent Variable: log(productivity)

\section{Firm's characteristics}

High Herfindahl

Low Herfindahl

High Import Penetration

Low Import Penetration

High Export Share

Low Export Share

Capital Goods

Intermediate Goods

Consumer Goods

Capital Intensive

Labor Intensive

Natural Resources Int.

Low Initial Tariff

High Initial Tariff

\section{Nominal Tariff}

$2.7280(0.8460)^{\star \star \star *}$

$-0.2975(0.2475)$

$-2.1946(0.3779)^{* * *}$

$-2.6878(0.2513)^{* * *}$

$-0.1326(0.6138)$

$-0.9078(0.1850)^{* * *}$

$0.3882(0.7800)$

$-2.5662(0.9799)^{* * *}$

-0.8404 (1.0644)

$3.3448(0.0916)^{\star \star \star}$

$3.4297(0.8832)^{\star *}$

$2.4526(0.8704)^{\star * *}$

$0.8942(0.4585)^{*}$

$-1.1735(0.3163)^{* * *}$

Small

Large

$0.1451(0.1242)$

$-0.0266(0.0772)$
Tariff on Inputs

$-1.7484(0.9892)^{\star \star \star}$

$0.0205(0.2844)$

$1.9547(0.4405)^{* * *}$

$2.0389(0.2626)^{* \star *}$

$0.4219(0.6042)$

$0.8100(0.2686)^{\star \star \star}$

$0.3519(0.8740)$

$3.4948(1.1232)^{* \star *}$

$1.6773(1.2145)$

$-2.5828(0.9820)^{\star * *}$

$-3.1061(0.9628)^{\star \star *}$

$-1.4564(0.9673)$

$-0.7864(0.4015)^{* *}$

$1.8134(0.3322)^{* * *}$

$0.3633(0.1919)^{*}$

$0.0127(0.1038)$

Includes year and industry fixed effects.

Robust standard errors into parenthesis.

$* * *, * *, *$ : significant at $1 \%, 5 \%$ and $10 \%$, respectively. 
TABLE 8 - FIRM'S PRODUCTIVITY BY INDUSTRY

\begin{tabular}{|c|c|c|c|c|c|c|}
\hline & \multicolumn{2}{|c|}{1988} & \multicolumn{2}{|c|}{1992} & \multicolumn{2}{|c|}{19998} \\
\hline & Mean & Stand. Dev. & Mean & Stand. Dev. & Mean & Stand. Dev \\
\hline 4 Non-metal mineral products & -0.316 & 0.522 & -0.460 & 0.521 & -0.577 & 0.501 \\
\hline 5 Basic metal products & 0.180 & 0.415 & 0.117 & 0.373 & 0.093 & 0.440 \\
\hline 6 Non-ferrous metal products & 0.128 & 0.418 & 0.115 & 0.358 & 0.137 & 0.347 \\
\hline 7 Metal products & 0.162 & 0.445 & -0.073 & 0.344 & 0.086 & 0.354 \\
\hline 8 Machinery and equipment & -0.146 & 0.502 & -0.135 & 0.438 & -0.078 & 0.425 \\
\hline 10 Electrical equipment & 0.078 & 0.494 & 0.867 & 0.567 & 1.304 & 0.430 \\
\hline 11 Electronic equipment & 0.149 & 0.545 & 0.178 & 0.341 & 0.420 & 0.551 \\
\hline 12 Automobiles, trucks and buses & -0.023 & 0.454 & -0.075 & 0.318 & 0.111 & 0.167 \\
\hline 13 Other Vehicles and parts & 0.260 & 0.379 & 0.171 & 0.286 & 0.596 & 0.335 \\
\hline 14 Wood and furniture & -0.240 & 0.369 & -0.491 & 0.360 & -0.495 & 0.430 \\
\hline 15 Paper, pulp and cardboard & -0.040 & 0.458 & 0.015 & 0.331 & 0.118 & 0.395 \\
\hline 16 Rubber products & 0.204 & 0.524 & 0.064 & 0.450 & 0.006 & 0.466 \\
\hline 17 Non-petrochemical chemical elements & 0.196 & 0.455 & 0.110 & 0.437 & 0.121 & 0.476 \\
\hline 18 Basic petrochemical products & -0.071 & 0.363 & -0.248 & 0.304 & -0.205 & 0.284 \\
\hline 19 Chemical products & 0.239 & 0.500 & 0.143 & 0.375 & 0.161 & 0.459 \\
\hline 20 Pharmaceutical products and perfume & 0.122 & 0.519 & -0.170 & 0.426 & -0.591 & 0.480 \\
\hline 21 Plastics & 0.030 & 0.466 & 0.087 & 0.376 & -0.036 & 0.395 \\
\hline 22 Textiles & 0.087 & 0.531 & 0.092 & 0.591 & 0.000 & 0.413 \\
\hline 23 Apparel & 0.011 & 0.537 & -0.152 & 0.503 & 0.190 & 0.433 \\
\hline 24 Leather Products and footware & -0.024 & 0.635 & -0.273 & 0.363 & -0.268 & 0.263 \\
\hline 25 Coffee products & 0.400 & 0.680 & 0.234 & 0.451 & -0.041 & 0.299 \\
\hline 26 Processed edible products & 0.051 & 0.461 & -0.152 & 0.569 & -0.117 & 0.423 \\
\hline 27 Meat and Poultry & -0.027 & 0.459 & -0.142 & 0.315 & -0.117 & 0.220 \\
\hline 28 Processed dairy products & 0.046 & 0.462 & -0.241 & 0.316 & -0.323 & 0.388 \\
\hline 29 Sugar & 0.293 & 0.405 & 0.040 & 0.466 & 0.249 & 0.419 \\
\hline 30 Vegetable oil & 0.025 & 0.409 & -0.026 & 0.410 & 0.142 & 0.547 \\
\hline 31 Beverage and other food products & 0.172 & 0.712 & 0.047 & 0.520 & -0.071 & 0.449 \\
\hline
\end{tabular}

TABLE 9 - QUANTILE REGRESSION - RELATIVE PRODUCTIVITY AND TARIFFS

\begin{tabular}{|c|c|c|}
\hline $\begin{array}{l}\text { Dependent Variable } \\
\text { log(prod) - decile }\end{array}$ & Nominal Tariff & Tariff on Inputs \\
\hline \multirow[t]{2}{*}{1} & -0.1969 & -0.2447 \\
\hline & $(0.0602)^{\star \star *}$ & $(0.1161)^{\star *}$ \\
\hline \multirow[t]{2}{*}{2} & -0.1059 & -0.2695 \\
\hline & $(0.0478)^{* *}$ & $(0.0894)^{* * *}$ \\
\hline \multirow[t]{2}{*}{3} & -0.1102 & -0.2420 \\
\hline & $(0.0432)^{* *}$ & $(0.0782)^{\star * \star}$ \\
\hline \multirow[t]{2}{*}{4} & -0.0640 & -0.2585 \\
\hline & $(0.0442)$ & $(0.0795)^{* \star *}$ \\
\hline \multirow[t]{2}{*}{5} & -0.0286 & -0.2279 \\
\hline & $(0.0450)$ & $(0.0789)^{\star * *}$ \\
\hline \multirow[t]{2}{*}{6} & 0.0933 & -0.3209 \\
\hline & $(0.0446)^{* *}$ & $(0.0760)^{* * *}$ \\
\hline \multirow[t]{2}{*}{7} & 0.1484 & -0.3646 \\
\hline & $(0.0504)^{* * *}$ & $(0.0830)^{* * *}$ \\
\hline \multirow[t]{2}{*}{8} & 0.1955 & -0.3691 \\
\hline & $(0.0500)^{* * *}$ & $(0.0788)^{* * *}$ \\
\hline \multirow[t]{2}{*}{9} & 0.3305 & -0.4196 \\
\hline & $(0.0813)^{\star * *}$ & $(0.1228)^{\star * *}$ \\
\hline
\end{tabular}

Include year and industry fixed effects.

Robust standard errors into parenthesis.

$* * *, * *, *$ : significant at $1 \%, 5 \%$ and $10 \%$, respectively. 